\title{
Materiały do historii altarystów kościoła Mariackiego w Krakowie w średniowieczu Część 2: Statuty domu altarystów
}

\begin{abstract}
Zarys treści: Publikacja zawiera krytyczną edycję wraz z komentarzem nieznanych dotąd, zachowanych w redakcji z 1437 r., liczących 24 paragrafy, statutów domu altarystów kościoła Wniebowzięcia Panny Marii (Mariackiego) w Krakowie - jedynych tego typu znanych z terenu historycznego Królestwa Polskiego.
\end{abstract}

Abstract: The paper contains a critical edition together with commentary of the statutes of the house of altarists of Virgin Mary Church in Cracow. So far unknown and preserved in the redaction from 1437, these statutes of 24 articles are the only source of this type from the area of the historical Kingdom of Poland.

Słowa kluczowe: średniowieczny Kraków, kościół Mariacki w Krakowie, kler parafialny, bractwa kapłańskie, vita communis, statuty

Keywords: medieval Cracow, Virgin Mary Church, parochial clergy, priestly fraternity, vita communis, statutes

Przed dwoma laty wspólnie z Bożenną Wyrozumską opublikowaliśmy krytyczną edycję zachowanych w piętnastowiecznej kopii, a nieznanych dotąd literaturze przedmiotu, kalendarza i nekrologu prowadzonego przez konfraternię altarystów sprawujących posługę w największym kościele parafialnym średniowiecznego Krakowa ${ }^{1}$. Zabytki te znajdują się w rękopisie niegdyś przechowywanym w domu altarystów mariackich, obecnie zaś należącym do zbiorów Archiwum Narodowego w Krakowie ${ }^{2}$. Mieści on także inne teksty dotyczące dziejów owego domu, w tym datowane na 1437 r. statuty, których edycję wówczas zapowiadaliśmy i które stanowią główny przedmiot zainteresowania niniejszego tekstu ${ }^{3}$.

Jak wiadomo, prebendarze, czyli duchowni dysponujący beneficjami, z którymi nie wiązały się prawa parafialne, stanowili największą liczebnie grupę wśród kleru parafialnego. Wśród nich wyróżnia się właśnie altarystów, prepozytów szpitalnych

${ }^{1}$ B. Wyrozumska, M. Starzyń s ki, Materiały do historii altarystów kościoła Mariackiego w Krakowie w średniowieczu, cz. 1: Kalendarz i nekrolog oraz katalog altarystów i benefaktorów, Roczniki Historyczne 84, 2018, s. 259-291.

${ }^{2}$ Kraków, Archiwum Narodowe, rkps nr 3361.

${ }^{3}$ B. Wyrozum ska, M. S tarzyń s ki, Materiały, s. 267. 
oraz posiadaczy prebend w kapitułach ${ }^{4}$. Eugeniusz Wiśniowski, w jedynej dostępnej, choć nienajlepszej syntezie poświęconej organizacji parafialnej w średniowiecznej Polsce, słusznie podnosił, że u genezy wykształcenia się altarystów jako odrębnej grupy duchowieństwa parafialnego stała po prostu mentalność religijna człowieka średniowiecza oraz jego „dążenia do zapewnienia sobie zbawienia poprzez fundacje mszalne"s. Uposażony w odpowiedni sposób kapłan zobowiązany był do odprawiania $\mathrm{w}$ określone dni mszy w intencji fundatora, nie był natomiast $\mathrm{w}$ zasadzie związany $\mathrm{z}$ pracą duszpasterską. Takie funkcje przypadały też w udziale altarystom sprawującym posługę jako sacerdotes loci w krakowskim kościele Mariackim.

W literaturze przedmiotu od dawna podkreśla się wpływ, jaki życie zakonne (monastyczne) wywierało właśnie na duchowieństwo świeckie (diecezjalne). Miało się to przejawiać przede wszystkim w organizowaniu wspólnot modlitewnych (genezę tych odnosi się jeszcze do doby karolińskiej ${ }^{6}$ ), które z czasem zaczęto określać jako fraternitates spirituales bądź fraternitates presbyterorum 7 . W Europie Zachodniej powstawały one już w XII i XIII stuleciu, najwcześniej w prowincjach nadreńskich Rzeszy Niemieckiej, następnie na Półwyspie Iberyjskim oraz we Francji. Ich rozwój przypadł jednak głównie na XIV i XV w. ${ }^{8}$ Funkcjonowanie owych bractw kapłańskich wpisuje się w znacznie szersze zagadnienie, jakim był ruch bracki, stanowiący jedną $\mathrm{z}$ emanacji tak charakterystycznego dla średniowiecza korporacjonizmu, obecnego nie tylko w sferze gospodarczej, ale także w szeroko rozumianej sferze społecznej, obejmującej również życie religijne. Wyrastając z benedyktyńskiego „zwyczaju łączenia się poszczególnych domów zakonnych we wspólnym zobowiązaniu, by się wspierać nawzajem modlitwą", ruch bracki w pierwszej kolejności wiązał się

${ }^{4}$ E. W i śn i ow sk i, Parafie w średniowiecznej Polsce. Struktura i funkcje społeczne, Lublin 2004, s. 105; I. S k i e r s k a, Obowiązek mszalny w średniowiecznej Polsce, Warszawa 2003, s. 118.

${ }^{5}$ E. W i ś n i o w s k i, Parafie, s. 105; zob. także J. O b e r s t e, Gibt es eine urbane Religiosität des Mittelalters?, w: Städtische Kulte im Mittelalter, Regensburg 2010 (Forum Mittelalter. Studien 6), s. 15-36; K. K u i k e n, Rural Salvation Markets. Medieval Memoria in Dutch Village Parisches, Groningen 2019 (Historia agriculturae 49).

${ }^{6}$ G.G. M e e r s s e m a n, Die Klerikervereine von Karl dem Großen bis Innocenz III, Zeitschrift für schweizerische Kirchengeschichte 46 1952, s. 1-42, 81-112.

${ }^{7}$ G. Tarbo ch ez, Les communautés de prêtres séculiers en France à la fin du Moyen Âge, Revue d'histoire de l'église de France 93, 2007, s. 229-248.

${ }^{8}$ G. de Leotoing d'Anjony, La communauté des prêtres-filleuls de l'église Notre-Dame d'Aurillac, Revue de la Haute-Auvergne 33, 1952-1953, s. 289-301, 372-382, 446-459; 34, 1954-1955, s. 30-56, 111-124, 169-188; P. J e u n i a u x, Les communautés de "prêtres-filleuls". Longévité d'une institution née au XIVe siècle, Mémoires de la Société des Sciences Naturelles et Archéologiques de la Creuse 42, 1984-1986, s. 71-82; K. H e n g s t, "Fraternitas sacerdotum in Herfordia". Die Dreifaltigkeitsaland in Herford, w: Lob der brüderlichen Eintracht. Die Kalandsbruderschaften in Westfalen. Festschrift aus Anlaß des 650-jährigen Bestehens der Kalandsbruderschaft in Neuenheerse, Paderborn 2000 (Veröffentlichungen zur Geschichte der mitteldeutschen Kirchenprovinz 17), s. 47-49; P. E 1 b e 1, N. K r u p a, Die Fraternitas XXIV plebanorum civitatum regalium in Oberungarn und der Handschriftenbestand Zipser Pfarreibibliotheken, w: Pfarreien im Mittelalter. Deutschland, Polen, Tschechien und Ungarn im Vergleich, Göttingen 2008 (Studien zur Germania Sacra 32), s. 327-338.

9 E. W i ś n i o w s k i, Parafie, s. 190 (rozdział poświęcony bractwom w cytowanej monografii to właściwie uzupełniony przez autora starszy artykuł: Bractwa religijne na ziemiach polskich w średniowieczu, Roczniki Humanistyczne 17, 1969, s. 51-81). 
z powstawaniem konfraterni klasztornych, dalej wspominanych już konfraterni duchowieństwa świeckiego, by w ostatniej fazie swojego rozwoju doprowadzić do zawiązywania się różnych zrzeszeń ludzi świeckich: dewocyjnych, charytatywnych (szpitalniczych) czy pokutniczych ${ }^{10}$.

E. Wiśniowski oceniał za starszą literaturą, że „na Pomorzu Zachodnim spotykamy ich [tj. bractw kapłańskich - M.S.] w omawianym okresie około 43, w diecezji poznańskiej - około 19, taką samą liczbę w diecezji wrocławskiej na początku XVI w." "11 Jeśli idzie o Małopolskę, to najstarsze znane dziś bractwo tego typu dowodnie funkcjonowało już w latach siedemdziesiątych XIV w. w dekanacie zatorskim diecezji krakowskiej (1378) ${ }^{12}$. Bolesław Kumor przed blisko 60 laty doliczył się jeszcze dziewięciu dalszych takich konfraterni ${ }^{13}$. W kontekście niniejszych rozważań szczególnego znaczenia nabiera wzmianka w dokumencie z 26 VIII 1383 r. wystawionym przez kardynała Demetriusza, legata w królestwach Węgier i Polski. Mocą tego dyplomu słuchający mszy ku czci Bożego Ciała, celebrowanych we czwartki przy ołtarzu pod tym samym wezwaniem w kościele Mariackim w Krakowie, mieli uzyskać odpust w wysokości roku i stu dni. Nabożeństwa te zostały zaś ustanowione przez działające przy tym kościele bractwo kapłanów i mieszczan (confraternitas presbiterorum ac civium Cracouiensium) ${ }^{14}$. Obok bractwa mariackiego znane było ponadto bractwo w Pilźnie (od XVII w. nazywane arcybractwem), erygowane przez

${ }^{10}$ B. K u m or, Kościelne stowarzyszenia świeckich w okresie przedrozbiorowym, Prawo Kanoniczne 10, 1967, s. 289-356; H. Z a r e m s k a, Bractwa w średniowiecznym Krakowie. Studium form społecznych życia religijnego, Wrocław 1977; I. C z a r c iń ski, Bractwa w wielkich miastach państwa krzyżackiego w średniowieczu, Toruń 1993. Nowsze spojrzenie na tę problematykę prezentują teksty zebrane w tomie: Bruderschaften als multifunktionale Dienstleister der Frühen Neuzeit in Zentraleuropa, Wien 2018 (Veröffentlichungen des Instituts für Österreichische Geschichtsforschung 70), np. Z. O rl i ta, Fromme Bruderschaften in Böhmen, Mähren und Schlesien. Ein Forschungsüberblick, s. 67-86, A. F o r g ó, Bruderschaften in Ungarn. Eine Forschungsbilanz, s. 87-114.

${ }^{11}$ E. Wiśni owski, Parafie, s. 195; zob. też J. Gotts chalk, Das Totenbuch der Altaristenbruderschaft von Maria Magdalena zur Breslau ca. 1454-1524, Archiv für schlesische Kirchengeschichte 6, 1941, s. 127-185; H. H e y d e n, Kirchengeschichte Pommerns, t. I, Köln 1957, s. 161-163; J. N o w a c k i, Dzieje archidiecezji poznańskiej, t. II, Poznań 1964, s. 737-741; W. R a c z k ow s k i, Konfraternie duchownych w wielkopolskiej części diecezji poznańskiej w okresie przedtrydenckim (XV-XVI w.), Lublin 1966 (maszynopis).

${ }^{12}$ S. K u r a ś, Statuty i przywileje bractwa kapłanów dekanatu zatorskiego 1378-1525, Polonia Sacra 7, 1955, s. 255-260.

13 Statuty bractwa kapłańskiego oficjałatu pilzneńskiego przy kościele św. Jana Chrzciciela w Pilznie, wyd. B. Kumor, Archiwa Biblioteki i Muzea Kościelne 5, 1962, s. 385-387.

14 Kodeks dyplomatyczny miasta Krakowa, t. III, wyd. F. Piekosiński, Kraków 1882, nr 389; W. S z y m b o r s k i, Odpusty w Polsce średniowiecznej, Kraków 2011, s. 349, nr 440. H. Z a r e m s k a, Bractwa, s. 48, która powątpiewała, że w parafii Mariackiej istniały wówczas dwa bractwa, dla których osobne dyplomy w 1383 r. wystawił kardynał Demetriusz, tj. confraternitas civium Cracovienisum oraz confraternitas persbiterorum ac civium Cracoviensium; uznała nadto, że bractwo wymienione w cytowanym dokumencie Demetriusza zanikło „na przełomie XIV i XV w., być może w związku z powstaniem domu i wspólnoty altarystów, co wywołać zapewne musiało odpływ kleru z konfraterni”. Mając na względzie ustalenia poczynione w pierwszej części niniejszego artykułu, należy uznać, że konfraternia kapłańska z 1383 r. była tożsama z późniejszą wspólnotą altarystów. 
biskupa Piotra Wysza w 1410 r. ${ }^{15} \mathrm{Z}$ pierwszej połowy XV w. pochodzi wzmianka o bractwie starosądeckim zorganizowanym przez biskupa Zbigniewa Oleśnickiego ${ }^{16}$. Przed 1468 r. istniało już bractwo Ducha Świętego w dekanacie bobowskim ${ }^{17}$ oraz kolejne w dekanacie bieckim ${ }^{18}$. Do czasów pontyfikatu biskupa Jana Rzeszowskiego (1471-1488) odnoszą się najpewniej wzmianki o podobnych bractwach w Wieliczce i Strzyżowie ${ }^{19}$. Piętnastowieczną metrykę miało również bractwo kapłańskie w Myślenicach ${ }^{20}$. Z kolei do diecezji przemyskiej odnoszą się wzmianki o bractwach w Łańcucie (statuty z 1450 r. ${ }^{21}$ ) oraz w Sanoku i Krośnie (1449, 1452, $1455)^{22}$. Zachowanymi statutami dysponujemy jednak tylko dla bractw: zatorskiego (czternastowiecznymi, ale znanymi z późnej, osiemnastowiecznej kopii), łańcuckiego (dyplom biskupa przemyskiego Piotra z 5 XII 1450 r.) oraz pilzneńskiego (z 1481 r., znane w siedemnastowiecznej redakcji).

W pierwszej części niniejszego artykułu, analizując wpisy obituralne w kalendarzu altarystów mariackich, wysunęliśmy przypuszczenie, że był on prowadzony już w XIV w. ${ }^{23}$ Znajduje to potwierdzenie w cytowanym wyżej dokumencie kardynała Demetriusza z 1383 r., wskazującym na dowodne istnienie konfraterni kapłańskiej przy kościele Mariackim, czyli najpewniej właśnie bractwa altarystów. Kilkanaście lat później, w 1397 r., dzięki legatowi Jakuba Silbera zakupiono dom przy Małym Rynku, który został objęty opieką przez władze komunalne Krakowa ${ }^{24}$. Wtedy także po raz pierwszy, jakkolwiek dość ogólnie, zostały uregulowane obowiązki ciążące na mieszkańcach tego domu. Pierwszeństwo w otrzymaniu w nim izby przysługiwało kapłanom obsługującym altarie znajdujące się pod patronatem rady miejskiej. Każdy nowy mieszkaniec był zobligowany do posiadania stosownego instrumentu notarialnego zawierającego obietnicę przykładnego życia w tej korporacji. Konieczność spisania bardziej szczegółowych reguł normujących zasady vitae communis pojawiła się nieznacznie później.

Statuty domu altarystów mariackich są pod wieloma względami wyjątkowe jeśli idzie o zachowany materiał źródłowy z terenu średniowiecznego Królestwa Polskiego. Treściowo, jako statuty domu, różnią się bowiem od zachowanych statutów łańcuckich, pilzneńskich i zatorskich, regulujących przede wszystkim powinności liturgiczne członków. Bliżej jest im natomiast do statutów kolegiów uniwersyteckich. Zofia Kozłowska-Budkowa jakże trafnie charakteryzowała przed laty instytucję kolegium: „Ten pół klasztor, pół pensjonat łączący mistrzów przy wspólnym stole

15 Statuty, s. 387.

16 Tamże, s. 386.

17 Kraków, Archiwum Krakowskiej Kurii Metropolitalnej, Acta officialia 119, s. 1533 n.

18 Statuty, s. 386.

19 Matricularum Regni Poloniae summaria, t. III, wyd. T. Wierzbowski, Warszawa 1908, nr 1704; Statuty, s. 386.

20 Statuty, S. 386.

${ }^{21}$ Analecta ad historiam iuris canonici in dioecesi Premisliensi, wyd. B. Ulanowski, w: Archiwum Komisji Historycznej Akademii Umiejętności, t. V, Kraków 1889, s. 430-433.

${ }^{22}$ Akta grodzkie i ziemskie z czasów Rzeczypospolitej Polskiej z archiwum tak zwanego bernardyńskiego we Lwowie, t. XI, Lwów 1886, nr 2691, 3060 (fraternitas capellanorum), 3237, 3238.

${ }^{23}$ B. Wy rozu m s k a, M. S t a r z yń s k i, Materiały, s. 262.

${ }^{24}$ Kodeks dyplomatyczny katedry krakowskiej ś. Wacława, t. II, wyd. F. Piekosiński, Kraków 1883, nr 325. 
i na częstych zebraniach, zaopatrzony w bibliotekę, nad którą już w 1429 r. czuwało dwóch kustoszów, kolejno wybieranych spomiędzy mistrzów, połączony z salkami wykładowymi, poddany władzy wybieranego co semestr prepozyta czuwającego nad wewnętrzną dyscypliną i obdarzonego władzą sądową w tym zakresie, miał za zadanie - uwalniając swoich mieszkańców od kłopotów gospodarstwa domowego - podtrzymywać i rozwijać w nich aktywność umysłową i kulturę moralną"25. Mieszkańców kolegium obowiązywały więc ściśle określone rygory wspólnego funkcjonowania. „Moralności i prestiżu członka kolegium strzegły też stosunkowo liczne paragrafy statutów obwarowane karami, zakazujące obcowania sam na sam z białogłowami, nawet zacnymi, chodzenia nocą po mieście czy przebywania w lokalach nie cieszących się dobrą opinią" ${ }^{26}$. Co więcej, „statuty starały się usunąć też wszelkie sposobności do sporów i zadrażnień - - nakładając hamulec licznych kar pieniężnych na krewkie temperamenty za nieprzestrzeganie wzajemnego szacunku między kolegami i nieobyczajność" ${ }^{27}$. Nie inaczej miało wyglądać życie w domu altarystów mariackich.

Publikowane statuty opatrzone zostały w nagłówku datą 1437. Uważny czytelnik z pewnością zauważy jednak pewną niekonsekwencję chronologiczną, gdyż większość z wymienionych w prefacio osób już wówczas nie żyła. Uchwaliło je dziesięciu altarystów: Jan Scho'ntho'r, Jakub Zilber, Jan Byliczer, mistrz Mikołaj Goltberg (może ich redaktor, jako jedyny wymieniony wszak z tytułem magistra ${ }^{28}$ ), Piotr z Tyczyna, Piotr Grot, Mikołaj Kerber, Andrzej z Biecza, Mikołaj Czypser, Mikołaj Rolle, a także Jan Sebenwirt, rajca krakowski i benefaktor domu, celem poprawy obyczajów, co należy jednak rozumieć nieco przekornie, skoro chodziło o ich własne grono. Jedynymi wcześniejszymi regulacjami dotyczącymi mieszkańców domu były bowiem te zawarte w przywileju fundacyjnym z $1397 \mathrm{r}$. Scho ntho ${ }^{\mathrm{e}} \mathrm{r}$ zmarł w 1407, Zilber w 1408, Goltberg w 1429, Piotr z Tyczna w 1436, Grot w 1431, Kerber w 1431, Andrzej z Biecza w 1437, a Rolle w 1430 r. ${ }^{29}$ Mając to na uwadze, trzeba by przyjąć, że terminem ante quem redakcji tego zbioru przepisów, lub może raczej wszczęcia nad nim prac, był 1407 r., natomiast jego ukończenie przypadło dopiero trzy dekady później. W tym kontekście można dodać, że statuty najstarszego krakowskiego kolegium uniwersyteckiego znamy w redakcji z 1429 r., jakkolwiek wiadomo, że istniały jakieś starsze wersje ${ }^{30}$.

${ }^{25}$ Z. K o z ł ow s k a - B u d k o w a, Odnowienie jagiellońskie Uniwersytetu Krakowskiego (1390-1414), przedruk w: tejże, Studia z dziejów kultury sredniowiecznego Krakowa [1964], wybór S. Szczur, Kraków 2015 (Biblioteka Krakowska 146), s. 267. Dotychczasowe badania dotyczące kolegiów umiejętnie podsumował M. B a s te r, Bursa Stranigielska. Z dziejów kolegiów Uniwersytetu Krakowskiego w XVII i XVIII wieku, Kraków 2015 (Historia et monumenta Universitatis Jagellonicae IV), s. 45-67.

${ }^{26}$ Z. Ko złow s k a - B u d k ow a, Odnowienie, s. 267.

27 Tamże.

${ }^{28}$ Nasz mistrz Mikołaj Goltberg to najpewniej Mikołaj Goltberg z Nysy wypromowany na Wydziale Sztuk, bakałarz 1403, a następnie mistrz 1408 - Najstarsza księga promocji Wydziału Sztuk Uniwersytetu Krakowskiego z lat 1402-1541, wyd. A. Gąsiorowski, T. Jurek, I. Skierska, Warszawa 2011, s. 194 (nr 03/4), s. 196 (nr 08/9).

29 B. Wy r o z u m s k a, M. S t a r z y ń s k i, Materiały, s. 284-286.

${ }^{30}$ Statuta antiqua Collegii Maioris, wyd. J. Szujski, w: Archiwum do dziejów literatury i oświaty w Polsce, t. I, Kraków 1878, s. 1, 3; zob. D. W ó j c i k-Z e g a, Codex legum 
Redaktor publikowanych statutów domu altarystów (statuty zachowały się w kopii z połowy lat osiemdziesiątych XV w. sporządzonej przez Marcina z Bochni, altarystę ołtarza św.św. Piotra i Pawła fundacji rajców krakowskich ${ }^{31}$ ), ze swobodą poruszał się nie tylko w bogatym zasobie perykop ewangelicznych, ale nieobce były mu również pomniki prawa kanonicznego. Przedmowę otworzył zresztą wymownym cytatem ze starotestamentowej Księgi Jeremiasza: ,poprawcie postępowanie i wasze uczynki, a pozwolę wam mieszkać w tym miejscu" (Ier 7,3), by zaraz nawiązać do fragmentu XII księgi Metafizyki Arystotelesa mówiącego o tym, że świat nie chce być źle rządzony ${ }^{32}$. Trudno zresztą o lepsze wprowadzenie do tekstu dotyczącego zarządu domu zamieszkiwanego przez mariackich kapłanów.

Zgodnie ze statutami wspomniany dom altarystów miało zamieszkiwać dwunastu kapłanów w osobnych izbach. Do ich dyspozycji pozostawała także infirmeria oraz wewnętrzny ogród, przeznaczony oczywiście pro recreacione, ale także chroniący przed smrodem miasta (aer corruptus). Jest to jedno z nielicznych źródeł mówiących wprost o zapachu epoki, co zresztą samo w sobie godne byłoby osobnego opracowania. Na czele wspólnoty stał prepozyt wybierany na miesięczną kadencję zgodnie ze starszeństwem obecności w domu (§ 12). Opłata dla każdego nowego jej członka wynosiła 3 grzywny (pro introitalibus), które następnie obracano na zakup sprzętów domowych (supellectilia) oraz bieżące naprawy $(\S 1,13)$. Znana jest także formuła przysięgi składanej przez każdego nowoprzyjętego, w której zobowiązywał się do przestrzegania statutów, w tym do poddawania się karom przewidzianym za złamanie tych przepisów (§ 13). Statuty miały być zresztą odczytywane dwa razy w roku (§ 20), około dni świętych Urbana (25 maja) i Andrzeja (30 listopada). Altaryści spotykali się, podobnie jak uniwersyteccy kolegiaci, przy wspólnym stole (§ 1), który utrzymywali, płacąc co poniedziałek przed zachodem słońca 6 groszy $(\S 4)$ i przy którym zasiadali w określonym porządku $(\S 20)$. Nieobecność była dopuszczalna tylko w szczególnych wypadkach ( $(5)$. Nakazywano też trzymanie na wodzy języka tak w stosunku do aktualnego prepozyta, jak i w dysputach tocznych między pozostałymi altarystami, którzy nie powinni wchodzić sobie w słowo (§ 15). Zajmowane izby mieli utrzymywać w dobrym stanie (§ 3). Służbę ograniczono do dwóch osób (§ 7). Przestrzegano też mieszkańców przed używaniem słów określanych jako scurilia et impudica, odpowiednich dla świata nierządnic, szczególnie wobec przygotowującej posiłki kucharki (§ 8), co najwidoczniej przytrafiało się dosyć często. Odwołując się do cytatu z 1 Listu do Tesaloniczan (5,22): „Unikajcie wszystkiego, co ma choćby pozór zła”, zabraniano altarystom kontaktów z kobietami podejrzanej reputacji. Pozwalano natomiast na prowadzenie rozmów w izbach przy otwartych drzwiach, jeśli danej kobiecie towarzyszyła druga (§9). Precyzyjnie określano również czas zamknięcia bramy domu (latem o godzinie drugiej po zachodzie słońca, zimą zaś

venerabilis communitatis Collegii Maioris. Studium kodykologiczno-źródłoznawcze księgi statutów Kollegium Większego Uniwersytetu Krakowskiego (Archiwum Uniwersytetu Jagiellońskiego, rękopis 68), w: Felix indiget amicis. Studia z dziejów kultury duchowej i intelektualnej średniowiecza ofiarowane Profesorowi Krzysztofowi Ożogowi, Kraków 2016, s. 231-275.

${ }^{31}$ B. Wy ro z u m s k a, M. St a r z y ń s k i, Materiały, s. 262.

${ }^{32}$ Por. M.L. Gi11, Unity of Definition in Metaphysics H.6 and Z.12, w: Being, Nature and Life in Aristotle, Cambridge 2010, s. 97-121. 
o godzinie trzeciej, § 10). Karano nie tylko sprowadzanie na noc osób postronnych, ale i nocowanie poza domem ( $§ 10-11)$. Posiadano nadto bibliotekę, nad którą pieczę sprawowało dwóch kustoszy (§ 24).

Publikowany tekst znacząco, jak się wydaje, wzbogaca dotychczasową wiedzę o tego typu instytucjach życia wspólnego w Polsce średniowiecznej, stanowiąc oczywiście podstawę do dalszych, pogłębionych studiów. Edycja przygotowana została zgodnie z zasadami wyłożonymi w instrukcji opracowanej przez Władysława Semkowicza ${ }^{33}$. Początek stron rękopisu zaznaczany jest w tekście w nawiasach kwadratowych. Fragmenty tekstu wypisane w rękopisie rubrą oddano pogrubioną czcionką. Pominięto natomiast nowożytne noty treściowe, będące oczywiście śladem bieżącej lektury, ale nic nie wnoszące do treści publikowanych przepisów. Rozpoznane cytaty, głównie biblijne, ujęto w cudzysłowy. Jeżeli zaś redaktor w sposób wyraźny nawiązywał np. do tekstu Pisma Świętego, w przypisie przywołano dosłowną treść odnośnego fragmentu. Dla przejrzystości kolejnym statutom (poza preambułą oraz generaliami) nadano osobną numerację, umieszczoną w nawiasach kwadratowych. Pan dr Krzysztof Nowak z Pracowni Słownika Łaciny Średniowiecznej w Polsce Instytutu Języka Polskiego PAN w Krakowie zechce przyjąć specjalne podziękowania za trud lektury publikowanych statutów pod kątem poprawności filologicznej.

\section{TEKST ŹRÓDŁOWY}

Statuty domu altarystów kościoła Mariackiego w Krakowie

Kop.: Kraków, Archiwum Narodowe, rkps nr 3361, s. 89-113.

Incipit prefacio in statuta domus altaristarum eclesie sancte Marie in Cracovia retro maccella carnificum in acie site anno Domini millesimo $\mathrm{CCCC}^{\circ} \mathrm{XXXVII}$. Pater sancte, in unione amoris amantissimi Filii Tui, in quo ipse humanam naturam in se accepit, comendo Tibi modo spiritum meum.

Novas „facite vias vestras et studia vestra et habitabo vobiscum in loco isto”, Jere(mie) VII ${ }^{1}$. Quia ,encia”, teste Aristotele in fine XII Metaphisice, „nolunt disponi male"2, hinc est, quod nos Johannes Scho ${ }^{\mathrm{e}}$ tho ${ }^{\mathrm{e}}$, Jacobus Zoelber, Johannes Byliczer, magister Nicolaus Goltberg, Petrus de Tyczen decanus, Petrus Groth, Nicolaus Kerber, Andreas de Byecz, Nicolaus Czypszer, Nicolaus Rolle altariste domus ipsius altaristarum, videlicet eclesie sancte Marie in Cracouia retro maccella lanistarum in acie versus scolam eiusdem eclesie situate mansuri tuncque presentes cum famoso Johanne Zebenwert consule Cracouiensi, precipuo benefactore et fratre domus, videntes, quia non esset conveniens neque bonum, nec eciam caritatis pacisque atque concordie conservaturum abs aliquali ordinacione et lege descripta in comunitate huiusmodi ita plane demorari, ad quam legem singulorum dominorum altaristarum, videlicet

${ }^{33}$ Instrukcja wydawnicza dla średniowiecznych źródeł historycznych, w: Archiwum Komisji Historycznej PAU, t. XIV, Kraków 1930, s. 1-40; przedruk w: J. Tandecki, K. Kopiński, Edytorstwo źródeł historycznych, Warszawa 2014, s. 311-327.

1 Ier 7,3.

2 Aristoteles, Metaphisica 12,10, w: Aristoteles latinus, t. XXV.3, pars secunda, wyd. G. Vuillemin-Diem, Turnhout 1995, s. 269, w. 535: Entia uero non uolunt disponi male, nec bonum pluralitas principatuum. 
ibidem degencium, certus utique haberetur respectus habitusque unusquisque in ibidem constitutus consequerentur se ipsum posset decenter per singula inter fratres regulari, de communi omnium et singulorum dominorum altaristarum imo fratrum predictorum voluntate, certa sciencia, consensu et annuencia prehabitis, tamen ante omnia super predicta [sic!] satis deliberacione diuturna doctorumque consiliis, nullius preiudicium procurari, sed bonum comune homine [sic!] in utroque intendentes per hoc ipsum promoveri, quedam certa puncta atque articulos nomine statutorum expresse [sic!] iam de facto colligentes descripsimus, volentes omnino totaliter descripta per fratres singulos dicte domus ${ }^{3}$, [s. 90] videlicet inpretermisse [sic!] nunc et in posterum perpetuis temporibus observari. Quapropter ad laudem Omnipotentis Dei Glorioseque Virginis Marie, sub cuius palliolo omnes et singuli militantes confovemur, gloriam videlicet et honorem nostramque ac nostrorum omnium et singulorum predecessorum pariter et successorum salutem, omnia et singula statuta infrascripta, que vias bonas et studia bona ${ }^{4}$ dicimus, volentes per ea bene disponi pro lege scripta iam de facto assumentes, quodlibet ipsorum statutorum de per se et singillatim sigillatimque et expresse a nobis fuco quovis simulacionis austere semoto omnes et singuli unanimiter approbantes laudabiliterque laudantes, obicem pertinacie nunc et in posterum omnino refallentes, statutum primum cum sequentibus iam de facto impositum vel in post eciam similiter imponendum irrecuse et irrefragabiliter statuimus observandum pariter et tenendum.

Secuntur quedam generalia alliciencia ad observanda statuta in hunc modum.

Quia antecessores nostri, patres et fratres nobis in Christo dilecti, quorum felicem modo agimus atque infra adhuc specialiter agemus memoriam, domum, in qua pro presenti habitantes demoramur, ipsorum de peculio elemosinisque hominum bonorum ipsis insuper ea gracia in subsidium utrumque pariter cum porrectis ipsimet [sic!] ipsorumque successoribus legittime intrantibus in perpetuum possidendam effectuose ementes compararunt emptamque rite et racionabiliter, ut in privilegiis domus prefate lacius continetur ac de hoc ipso eciam aliis certis punctis modo simili ibidem satis clare cavetur, ipsum precium totaliter persolventes ipsos venditores cum effectu arandarunt [sic!]. In ipsiusque domus tandem exinde plenariam taliter venientes possessionem, crebris diligentissime vicibus [s.91] pariter congregati mutuo conferentes pertractarunt, quo modo aut quo ordine atque qualiter ipsam iam eorum bene ordinarent atque disponerent hereditatem, pro qua tot atque tantos sumptus, labores simul et conatus non pauco tempore usque ad eiusdem consumacionem impendissent, ut laus, frequens et honor Deo Omnipotenti ante omnia et super omnia ipsisque simul et proximis salus inde iugis et profectus anime laudabiliter provenirent, damno eiusdem anime procul moto, quod ex ipsius negligenti hereditatis ipsorum disposicione dum peracta in ibi fierent et agerentur. Iusto Dei iudicio ipsos [sic!] indubitanter sequeretur, ut ita in ibi multiplicarent gentem, quod simul eciam et magnificarent leticiam ${ }^{5}$. Verum quia in multitudine hoc ipsum efficere apud ipsos quasi foret impossibile, ideo ipsi

${ }^{3} \mathrm{Na}$ dolnym marginesie tą samą ręką, błękitnym atramentem: Ihesus Christus Marie filius.

${ }^{4}$ Ier 7,3 .

5 Is 9,3: multiplicasti gentem non magnificasti laetitiam laetabuntur coram te sicut laetantur in messe sicut exultant quando dividunt spolia. 
tanquam viri experti, viri utique maturi, viri probati, viri Deum timentes pariter et amantes, scientes quod unum utique esset necessarium ${ }^{6}$ et quod „melior est unus timens Deum, quam mille filii impii"7, ne multitudo dictam ipsorum inhabitancium hereditatem sicut heu inde male satis hincinde alias expertum est, inter fratres confusionem germinaret et per consequens contencionum simul et iurgiorum de facili incomodum gravaret et taliter domino Deo per hoc ipsum perpessime displiceret, quia „ubi zelus et contencio ibi inconstancia et omne opus prawm" ${ }^{8}$ non nimis multos nec nimis eciam similiter paucos, sed me domini eligentes, ut quiecius scripture et studio lectioni et meditacioni, oracioni simul et contemplacioni, tanquam viri spirituales abs impedimento insolencie pro tempore invite [sic!] possent et tempus ipsis a Deo comodatum utiliter et bene expenderent in unione et fraterna caritate invicem conversando. Ipsam prefatam eorum hereditatem uti viri legitimique heredes huiusmodi hereditatis ipsorum prefate ad eternam laudem pariter et gloriam Omnipotentis primum suamque ac suorum predecessorum pariter et successorum simul eciam et benefactorum tam precedencium quam eciam sequencium salutem nec non eciam et ipsis proximis in boni exemplum pro duodecim personis in duodecim cameras, ut in ibi quiete habitarent et concorditer eo facilius viverent et pacate. Infirmariam insuper cum suo comodo eidem [ $s$. 92] contiguo pro usu solummodo infirmorum cameris supradictis adycientes sepefactam ipsorum hereditatem taliter, ut prefertur, construentes distinxerunt, ut clare patet ipsa eadem edificia intuenti plane per hoc ipsum et manifeste ipsorum ultimam dantes intelligi voluntatem et eorum publicum huiusmodi similiter testamentum siccine [sic!] ab eisdem, ut prefertur, ordinatum et usque ad mortem inviolabiliter tentum et observatum et taliter voluntate et morte eorum confirmatum ne quis post eos in ipsorum iamdicte destructionem hereditatis preiudicium et iacturam plura audeat edificia in ibi peramplius superedificare et supradictis utilitatem licet pretendens, factum tamen non intelligens edicere eorumque huiusmodi testamentum ac voluntatem ultimam taliter in hunc finem, ut prefertur, ab ipsis ordinatum atque dispositum, ausu temerario quovismodo infringere, paucis multa viciare et viciando inficere et per consequens anullare. Qui si plura in ibi habere voluissent comoda et personas similiter plures ibidem intendissent inlocare, ab ipso edificacionis exordio omnino sub labore et precio eadem utique construxissent, si eorundem confusionem tanquam experti non timuissent personarum. Quod et ipsis tutoribus domus et gubernatoribus eciam minime concedere voluerunt, uti manifeste hoc ipsum ostendit privilegium, quod de tutoribus vel ipsis gubernatoribus agens [sic!] dicit. Quod inhabitantes domum altaristarum debent notanter protegere, tueri et gubernare, non autem in ibi aliquid novi propter quoscunque novellos ab extra adhuc constitutos preter id, quod factum est augmentative, quicquam super edificare et contra voluntatem et intencionem heredum predictorum et eorundem pariter successorum plures in ibi collocando imponere edificia nowa propter ea edificiis plura addendo prioribus. Si vero priora, dum necesse fuerit, reficere voluerint bene possunt, sed nichil pluri apponere vel mutare etc.

\footnotetext{
${ }^{6}$ Lc 10,42: porro unum est necessarium.

7 Sir 16,3 .

${ }^{8}$ Iac 16,3 .
} 
His itaque siccine, ut premititur, racionabiliter ordinatis unam mensam insuper et unam scultellam, circum quam et [s.93] de qua omnes et singuli cum in presenciarum forent universi, simul sedentes hilariter verbum Domini audientes fraterne in Domino manducarent satis bene imo peroptime predicti patres ordinarunt, ut pax iugis et concordia, unio et caritas gaudiumque spiritus taliter inter fratres utique iuvante Domino inviolabiliter permaneret.

Quodque etiam posteriorem domus prefate partem pro ortulo haberi disponentes statureunt, ideo factum fore dinoscitur, ne supradicti fratres fracti laboribus, tociens quociens ipsis videretur fore necesse, camporum et silvarum, pratorum pariter et ortorum loca remota, tempus longum per hoc idem turpiter satis deprehendentes pro recreacione tali divagando, cogerentur queritare vel alias domus in civitate aliorum ea de causa similiter visitando penetrare et vana leviter valde resolvi per hoc ipsum, sed ut hoc idem cum profectu invenirent prope in domo, quod alibi vix longe quererent, sine damno, ut ad ipsa opera, que tunc necessarie interciperent, pro tempore breviter siccine recreati, vel alia pariformiter hisdem consonanter integri tandem cum gaudio remearent. Et ne eciam in domo prefata aer corruptus haberetur inclusus, qui de facili fratres ibi continue quasi in domo manentes inficeret et inficiendo mortem eisdem ante tempus procuraret; qui exinde in ibi concipitur atque per hoc ipsum permaxime generatur, quia ibi quasi tocius civitatis spurcicia tristegarum et fetor pariter tempore hiemis per regulos eductive preterfertur et alias dietim quasi civitatem effluendo domum preterfluit ut frequenter. Ut quociens aer corruptus taliter, ut prefertur, procuratus, domum prefatam ingreditur, tociens per aerem incorruptum et retentem fortuitu illac venientem dispergetur et ab inde ne fratres inficiet propulsetur. Et ut fons eciam quo domus nequaquam carere potest, [s. 94] comodose locum, tempore loco in alio habeat in futurum similiter et tristega, que alias locis in quinque egestionibus iam plena de facto est et solo tecta, locum eciam sicubi ibi in posterum fodiendi habeat aliquando.

Et ut infirmorum egestio abs dominorum nausea vel vomitu, ad que facillime exinde possunt effectualiter promoveri qui quotidie quasi se ad divina iuvante Domino disponere consueverunt officia, per partem posteriorem domus ipsius prefatam posset convenienter de infirmaria ad locum suum exportari. Et ut similiter ipsi infirmi ipsorum infirmitatibus pro tempore agitati interdum pro recreacione ad ortulum possent educi et aere simul et viridine utrumque in ibi refoveri. Patres nostri predicti verisimiliter pro sua suorumque conveniencia successorum ut veri legittimique heredes hereditatis ipsorum prefate ab ipso inicio ortulum prefatum cum ambitu simul instituentes, domum prefatam $\mathrm{i}<\mathrm{d}>$ circo, ut prefetur, edificiis occupando noluerunt condensare.

Quodque eciam patres nostri prefati altaristas [sic!] dominorum consulum civitatis Cracouiensis ecclesie Beate Virginis, videlicet in ipsorum hereditate huiusmodi, ut prefertur, locum eisdem sua sponte dantes in ibi principalem, cum se talis eisdem ad intrandum convenienter comodosus obtulerit, aliis omnibus et singulis altaristis in recepcione pretulerunt, hoc ideo per dictos patres comprobatur fore factum, ut ipsi domini consules tutores prefati huiusmodi munificam erga suos attendentes beneficenciam tanquam ipsismet factam, quod non oportet quantum ad numerum duodenarium supradictum pro loco et tempore ipsorum altaristas in civitate alias hospicium nullibi mendicare, ut eo solicius domum prefatam haberent in cura. Ante 
omnia tamen et pre omnibus ne comoda, preterquam ab ipsis heredibus patribus nostris prefatis sunt in ibi ordinata atque disposita, in destructionem domus ipsius et fratrum quovismodo sinerent fieri plura et eosdem similiter ab omnibus insultibus strennue et fideliter tanquam suos protegendo. Si autem secus fecerint, hereditas providebit.

[s. 95] Altariste autem ipsorum dominorum consulum antedicti et quivis alii, qui in domum, ut prefertur, pro tempore sunt recipiendi altaristarum predictam debent fore huiusmodi atque tales, qui in timore Dei consciencia, bona vita et moribus, quantum expedit homini intelligere atque scire ipsam ipsorum conversacionem erga Deum et homines tunc et in antea rite et racionabiliter notati et intellecti atque reperti sunt habere bonam. Qui insuper famam ipsorum bonam ubique laudabiliter in Domino conservarunt, qui patres simul et fratres domus ipsius in reverencia semper et honore habuerunt, qui non verbo nec facto domui iniurantes aliquando nocuerunt, qui eciam, cum per aliquam ad ibidem realem de facto vacanciarum se eisdem pro tempore locus intrandi obtulerunt, non cum impetu et turbine aliunde nolentes ascendere, sed intrare per ostium ${ }^{9}$ bono cum favore patrum simul et fratrum domus ipsius, primordialiter atque precipue locum prefatum pacifice et bono modo attentaveriint [sic!] obtinere. Qui vero secus fecerint idem ipsi et quivis capitose atque proprie voluntatis in antea comprobati, rixosi simul et contenciosi, lusores eciam et scandalosi, tales enim omnes atque huiusmodi, sive dominorum extiterint consulum, sive non iuxta primum nostrorum sanctionum [sic!], morem in domo et consuetudinem, et magis hoc modo patris statutiis [sic!] per hoc ipsum effecti inabiles, ad intrandum locum prefatum hac in domo non poterint obtinere, nec debent similiter adipisci in ibidem ita plane mansionem, et ut hoc ipsum a quovis pro lege in perpetuum haberetur. Ipsi patres prefati taliter, ut ordinaverunt $<$ ante $>$ quadraginta annis et amplius, ut idem pandit privilegium incorrupte, omnino et integre interim quod vixerunt, formam nobis nostrisque posteris in se ipsis preferendo ipsimet eadem tenendo voluerunt observare; nobis idem cum ipsius omnibus, quibus eis nobis convivere licuit temporibus, ut post [s. 96] ipsos consequenter taliter, ut reperimus eadem pariformiter inpretermisse iuvante Domino tenentibus atque agentibus usque modo.

Cum igitur antiqua bona et laudabilis qualiscunque consuetudo et observancia ubicunque aliquamdiu tenta pariter et observata pro lege utique consueta observari et presertim ubi laus Deo et honor, bonum hominum inde consuevit homine in utroque provenire. Et quia patres nostri, antecessores prefati, heredes veri atque legitimi huiusmodi hereditatis ipsorum prefate non solum consuetudinem bonam, que in ibi est diversa, quam in se ipsos a principio assumentes usque in finem, ut prefertur, ipsimet hilariter observarunt verumeciam et legem hereditariam, que maior quaque consuetudine fore scitur, que est domus ipsorum prefate in personas duodecim, ut prefertur, bene deliberata distinctio, nobis nostrisque posteris inviolabiliter et incorrupte pariter et inpretermisse post se testamento huiusmodi publico observandam relinquerunt. Potius utique una simul cum ceteris supradictis debebitur atque debetur observari. Quorum sequentur [sic!] testamenti instrumentum, est eorum huiusmodi hereditatis legitime urbaniter, ut patet, pro personis duodecim manifeste ordinata pariter in preperdita distinctio eiusdemque usque ad finem vite

\footnotetext{
${ }^{9}$ Por. Io 10,2: qui autem intrat per ostium pastor est ovium.
} 
per ipsosmet suosque successores equipolens usquemodo custodita obtencio, dans palam intelligi siccine, uti est disposita atque tenta deberi in posterum prout et debet perpetuis temporibus interrupte eciam et integre et a quibusvis in ibidem pariformiter observari etc.

Nos igitur altariste antedicti transgredere atque transgredi nolentes ordinata et disposita atque terminus, que et quos nobis nostrisque posteris, ut prefertur, patres nostri posuerunt, sed magis approbantes omnes et [s. 97] singulos laudamus atque laudantes approbamus approbantesque pariter et laudantes unusquisque nostrum de per se et singillatim sigillatimque et expresse et omnes simul universi omnia et singula puncta atque articulos domum nostrum hereditariam prefatam concernencia, eciam si non fuissent per patres nostros prefatos ad infra describendos taliter, ut predicitur, disposita atque eciam disponendo ordinata iam de facto assumentes, uti veri legitimique heredes talismodi hereditatis nostre prefate, ita atque tali habere volentes, ut prefertur. In nomine Domini statuimus, statuentes que per nosmet nostrosque posteros omnia et singula puncta atque articulos crebrefatam hereditatem nostram, ut premititur, concernencia, pure et integre pariformiter nunc et a modo perpetuis temporibus irrefregabiliter omnino volumus observari pariter et teneri. Quorum statutorum primum prosequimur in hunc modum, quod est tale.

\section{$[\S 1]$ Sequitur primum statutum.}

Quia omnes fructu comunitatis gaudere volentes eciam onera communitatis equaliter aliis tenentur sustinere, statuimus quod nullum deinceps liceat in domum altaristarum recipere, nisi ipse assumendus dictam domum de facto intrare voluerit intrandoque fratribus continue commanere nec non et onera dicte domus per singula spoponderit sustinere et ferre. Et quia nullus undecunque sit in hac domo altaristarum habet comodum speciale vel alias sibi appropriatum, sed omnia comoda in sortem vadunt communitatis, ita quod si eciam aliquem ex nostris altare suum cum quocunque casu contingat commutare iuxta morem in domo ab inicio observatum, non potest comodum in quo mansit concedere [sic!] comutanti, sed illud simpliciter comunitati redit, de quo fiet opcio iuxta morem, quia comunitas comunitati nichil plane tenetur, sed ipsam vacantiam ipsa comunitas dabit alteri per optionem cui placet. Pacta quoque iuxta veterem morem tunc [s. 98] et alias cum quod vacaverit comodorum opcione, quam iuste prior in domo tempore, si sibi placet inchoabit, quia qui prior est tempore pocior sit iure et qui sensit $\mathrm{om}<\mathrm{n}>$ is sentire debet et comodum. Ceteris fratribus similiter secundum in domo prioratum et morem idem consequentur, quibus placet agentibus ultimum locum, qui tunc vacabit taliter, ut premititur, assumptus tenebit. Et hoc idem debet intelligi de armariolis et locis circa mensam. Ita tamen quod nec claves pro domo nec eciam pro comodo sibi dentur, nec similiter quicquam in dictum comodum de rebus suis inferri paciatur nisi prius promissione facta de observandis in dicta domo iuribus cum tribus marcis pro incorporacione dicte domus et comodi atque rerum vel alias pro introitalibus iuxta morem antiquitus in antea observatum comunitati deponendo presentabit. Quas quidam tres marcas ipsa comunitas ab eodem tunc suscipiens iuxta observatum morem in domo easdem debet ubicunque viderit pro loco et tempore dictam comunitatem indigere pro bono comuni decenter convertere licet alias media marca de eisdem pro suppellectilibus ponebatur [sic!], due vero sexagene pro reformacione domus ipsius vel alias ubi necessitas comunitatem 
impellit taliter recepte expenduntur, quod parte pro utraque pariformiter, ut prefertur, cum eisdem fieri potest nunc et in posterum, sicut placet vel placebit.

Volumus etiam districte prohibendo statuentes, ne cuiquam altaristarum extra domum adhuc existencium aliqualis de cetero pro futura [sic!] expectanti promissio de habendo in domo comodo vel ullomodo emittatur, sed omnes et singuli tales atque huiusmodi plane expectent, donec vacanciam in eadem fieri contingat. Inde enim pullulare ceperat destructionis domus istius exordium et fratrum gravamen vere permaximum hoc parimodo supradictis adyciendo, decernimus ne eciam aliquando alter cum altero simul in domo manentes comutacionem facient comodis ipsorum nisi super hoc accedente deliberacione bona [ $s .99]$ comunitatis et consensu ne fraus interveniat et gravamen aliorum.

Hoc eciam adiecto supradictis, statuimus quod omnes in domo altaristarum manentes, qui duodenarium utique nullomodo debent excedere numerum iuxta decretum fundatorum habeant unam mensam comunem, ad quam quilibet manens in eadem sit astrictus, extra quam nulli licebit tenere proprias expensas in vel extra et mensam comunem refutare, nisi ad hoc comuni altaristarum concurrente favore; si autem aliquis contrarium presumpserit et sine speciali licencia prepositi prima ebdomada bursam dare recusaverit, det pro pena III grossos, si autem sequentibus ebdomadis non posuerit sine licencia prepositi et comunitatis pro qualibet solvat IIII grossos, tociens quociens ipsam hanc negligenciam frivole comittere contingat, exceptis infirmis quibus lex non est imposita et quibus census post recepcionem in domum perierunt.

Hoc quoque eciam non licuit silencio bene pretergredi, quando in perscriptis adyciendo foret statuendum, quod huiusmodi omnes et singuli taliter, ut premititur, absencie dediti in vel extra domum positi comodorum opcione simul et electione omnino carebunt quodcunque plane pro tempore vacaverit, tunc illorum preter illum duntaxat, qui in negocio domus solum simpliciter et pure sic ubi miteretur.

Placuit etiam hoc supradictis clarius exprimendo adycere, quod altarista absente procurator eiusdem, si quem habuerit, non potest pro primo introitu suo vel alias, ut infradicetur, nisi ipse altarista per se presens fuerit comodum pro eo in dicta domo ullomodo obtinere.

Omnis etiam altarista in dictam domum taliter, ut prefertur, iam defacto assumptus, sive huiusmodi in eadem sit domo continuus sive non, [s. 100] pro carbonibus et lignis in stuba comuni primum in infirmariam [sic!] eciam et coquina pariter pro bono comuni comuniter haberi conswetis per totum anni circulum ibidem necessariis de anno in annum, videlicet quamdiu commodum suum ipsius nomine in ibi steterit.

Pro precio eciam ibidem comunitati famulantium composicionibusque insuper pro reformanda domo, vel aliis intra et extra, ante et retro, infra et supra, circum et circa eandem domum, videlicet hic et ubique causam vel causas domus ipsius prefate duntaxat universaliter concernentibus, dictam comunitatem comuniter tangentibus universis, verisimiliter hisdem adiectis tanquam acsi presens foret prout ad hoc ipsum inprimis, ut predicitur, obligatus est ipso iure contribuere debet per singula et tenetur sub ipsa pena exclusionis a domo. Qui vero annuatim infrascriptas in marcas vel alias, ut dicitur, comunitati depagare voluerit, ad nichil aliud quam ad 
composiciones pro reformanda domo vel alias in et extra nuper tactas tantummodo sit astrictus.

Item, quibus census post recepcionem in domum quocunque modo deperirent, nullomodo debent de dicta domo removeri, quia afflictis adderetur afflictio, nisi tunc recedere vellent sua sponte.

$[\S 2]$ Ne comunitas per intrantes aliquomodo gravetur.

Quia scriptum est „currebant duo simul”"10, statuimus quod non is, qui pro primo verbo assumitur, in hac domo pocius ius habebit, sed qui de presenti et de facto prius intraverit et personali presencia alium vel alios prevenerit, locum occupando realiter prout antiquo iure hac in domo est semper et usque in presens observatur et iuste equidem, quia qui prior est tempore, pocior est in iure, ubi supra, et ne prorogacione intrancium comunitas aliquomodo aggravetur, quia semper magis attendi debet comune bonum quam personale vel proprium.

[ $\$ 3]$ Ne domus vel camere per intrantes pacientur detrimentum vel ruinam.

[s. 101] Quia nisi per inhabitatores domus, in comuni videlicet vel alias in speciali camerarum, domus et camere interpellatim et successive in primis et de recenti reformabuntur in aliqualiter corruptis vel confractis, domus et camere prefate miserabiliter in brevi patebunt ruine. Statuimus per presentes, quod quilibet dominorum altaristarum domo existens, habens in ibi cameram, debet et tenetur, imo eciam necessarie ad hoc ipsum astringitur in eadem camera sua vel ab extra, circum et circa, in quam ipsum imprimis vel alias quocienscunque racione opcionis quodcunque aliud intrare contigerit, aliquid novi et utilis pro melioracione ibidem dicte camere efficere et destructa similiter per se vel per alium sive eciam vetustate consumpta eadem reparare eorum quemlibet est necesse sub pena exclusionis a domo.

Premissa tamen super hec cum certo intervallo temporis monicione trina: si pro prima non fecerit, a mensa pro secunda excludatur; pro tercia vero tanquam ingratus et procax e domo finaliter expellatur, alias enim ipsa domus in ipsis edificiis pateretur detrimentum et iacturam, nec eciam quisquam predictorum pro tempore opcionis ad melius debet admiti comodum, nisi prius ostenderit predicta se fecisse ipso facto, vel alias id ipsum inpretermisse quantocius spoponderit se facturum et notanter quod in periculum comune vergit domus et ipse senior vel comunitas indixerit facienda sub pena modo tacta. Que senior ipse per se vel alium vel prepositus ipse assumptis aliquibus ex fratribus obligatur contemplari. Nullus eciam per opcionem vel alias de suo exiens comodo ad aliud, de eodem quidquam, quod illuc intrans invenit vel annexum quid per se in eodem effecerit, huic secum audeat asportare. Quod si quis hoc ipsum scienter fecerit per seniorem et comunitatem punietur asportatum cum dedecore viceversa reponendo.

\section{[\$ 4] Sequitur de bursa colligenda.}

[s. 102] Quia carencia pecunie impedit omne forum, statuimus quod quilibet altaristarum predictorum per anni circulum qualibet ebdomada debet dare bursam singulis feriis secundis semper ante occasum solis per sex grossos iuxta morem in domo observatum, ipsa solum caristie hora dempta. Quod si per prepositum admonitus fuerit et ipsam dare recusaverit, solvat pro pena unum quartensem; et si feria tercia

\footnotetext{
${ }^{10}$ Io 20,4 .
} 
monitus bursam non expediverit det pro pena unum grossum. Et si feria quarta sicut et alias per omnes vices ad infra ad supradictos frivole tamen eandem similiter non solverit, det pro qualibet vice pro pena similiter unum grossum. Hanc tamen penam, si comunitas per non solventem in comparacione victualium lesa non fuerit, poterit prepositus misericorditer relaxare.

[\$5] De modo ponendi bursam illorum, videlicet quos quocunque eventum in vel extra civitatem per aliquot certos dies in ebdomada a mensa communitatis contigerit absentari.

Quia impossibile fore videtur, quod homo in domo sit continuus, ut non aliquando vel ad modicum absentetur, statuimus, quod quilibet altaristarum predictorum, quem quocunque eventu de licencia tamen comunitatis extra civitatem in quibuscunque negociis propriis videlicet vel alterius cuiuscunque demptis solummodo causis comunitatis per aliquot certos dies vel ebdomadas a mensa comunitatis contigerit absentari, computatis diebus adventus ipsius huiusmodi eiusdem ebdomade solum, qua quot et quibus diebus rediens cum comunitate comederit, divisa bursa eiusdem ebdomade cum addicionibus suis in dies pro qua bursa propter absenciam suam in primis ipse non contribuit, pro qualibet die, qua taliter cum comunitate rediens comederit, tantum dabit comunitati, quantum computus diei cum addicionibus simul declarabit et econverso. Is autem, qui in civitate invitatus comederit, quotquot diebus in ebdomada hoc ipsum continuaverit, secundum antiquam domus ipsius conswetudinem solvat nichilominus comunitati cum addicionibus suis totam bursam. Cum vero omnes et singuli simul in civitate sicubi vel alias ubicunque ad prandium vocabuntur, nulli in domo seorsum pecunia de comuni [s.103] debet fieri prandium speciale, ceco duntaxat et claudo exceptis, sed de proprio sibi faciet in vel extra ne alii secum in domo occasionem simul manendi et comedendi capiant et comunitatem taliter gravem per hoc ipsum et ne eciam graciam quodammodo fratres vocandi per amplius in hominibus extingwant.

$[\S 6]$ Sequitur de hospitibus colligendis.

Quia Christum in peregrino et hospite recipi ${ }^{11}$ constat et huiusmodi refutare atque prohibere inhumanum supramodum fore patet, statuimus quod hospites quicunque adventantes pro tempore occurrerint et pro primo quidem prandio de licencia prepositi pro pluribus vero de licencia prepositi et comunitatis simul mensam dicte comunitatis accesserint et idem realiter et de facto comunicaverint cibisque bursalibus et conswetis contenti fuerint, iuxta taxam tunc prepositi comunitati facere debent satis; quam taxam idem prepositus consideratis pro tempore impensis et computatis habet atque in posterum semper habebit arbitrari. Si quis vero ex fratribus aliquem talium alcius voluerit honorare, de propriis facit hoc ipsum bonum commune non gravando.

\section{[\$ 7] De familia domus habenda.}

Quia pluralitas famulancium passim negligenciam parit et fures in domo generat atque gignit uno se altero excusante, statuimus quod universum totale comunitatis domus altaristarum predicte iuxta morem ibidem ab inicio observatum, uno famulo et famula una tantummodo sint contenti, qui bonum commune ante omnia expedire

${ }_{11}$ Por Mt 25,35: esurivi enim et dedistis mihi manducare sitivi et dedistis mihi bibere, hospes eram et collexistis me. 
sint astricti. Deinde eciam unicuique fratrum interpellatim et successive pro loco et tempore in ipsorum necessitatibus quociens requisiti fuerint, tenentur et debentur consequenter irrecuse deservire. Ita tamen, quod ceteri omnes et singuli altariste pacientur, sustineant et expectent quocienscunque unus illorum primordialiter et preventive a quocunque altaristarum suo singulari servicio fuerint occupatus quousque idem opus atque servicium taliter inceptum vel mox eciam incipiendum realiter et cum effectu per eundem terminetur.

[s. 104] Volumus eciam quod nulli omnino altaristarum servum proprium atque specialem in dicta domo continue manentem quovismodo fovere licebit preter ipsos decumbentes vel alias notabilibus pregravatos accedente ad hoc ipsum comunitatis voluntate et consensu. Potest tamen habere aliquem, qui interdum ad tempus sibi deserviet ad abscedat, ita tamen, quod omnino ortum non intret nec in eodem quidquam contingat, coquinam nonnisi missus visitet, nec in domo girowage hincinde discurrat, cameras domus vel infima ipsius suspective perlustrando, quod si per dominum suum non informatus vel alias hoc ipsum attentaverit, sine eciam quod displicet in domo fecerit et monitus cessare noluerit, domui per amplius non permitatur.

\section{$\left[\begin{array}{l}\S \\ 8\end{array}\right]$ De habenda conversacione cum familia.}

Quia familie nimia familiaritas contemptum parit dominorum et ad obsequia exequenda ut frequenter in benivolam negligentem et tardam imo eciam et rebellem atque in responsionem protervam reddere conswevit, statuimus quod omnes et singuli domini altariste honestam et publicam, simplicem et brevem cum familia habeant conversacionem et notanter cum coca ipsius domus. Quod si quis eorum in talibus visus fuerit modum excedere, per senioremque domus vel alias prepositum, quibus talia atque huiusmodi per ceteros dominos deferri debeant corrigenda, admonitus cessare a talibus noluerit, pro qualibet vice dabit pro pena II grossos. Quod si quis eciam dominorum ex ira vel alias quacunque levitate verba scurilia et impudica coram coca notanter protulerit vel alias improperiose vituperoseque more mundi meretricum lenociniumque, sive alia honores offensive eidem obyciendo obtenderit, sive eciam tale quid, quod spiritualem non licet personam, fecerit, pro qualibet vice dabit pro pena III grossos.

Volumus etiam omnino decernentes, quod coce domus nullus dominorum nimis sit familiaris et comunis, speciales sessiones et privatas in coquina vel alias cum eadem faciendo, quod si quis dominorum hoc ipsum sciens attentaverit, obiurgacione prius facta notabili iuxta decretum comunitatis si non destiterit, puniatur. Hoc similiter predictis adyciendo decernimus, quod nullus dominorum per se ipsum in familia debet recipere ulcionem ipsos videlicet verberando, sed siquid iniurie ad eadem cuiquam facto acci[s. 105]derit deferat preposito. Ille de remedio providebit, quod si quis nichilominus hoc postposito ipsos ausu temerario utique molestare presumpserit, tanquam qui bonum commune offendit, per comunitatem puniatur.

\section{[ $\$ 9]$ De honestate domus conservanda.}

Quia scriptum est „ab omni specie mala abstinete vos”" ${ }^{\prime 2}$, statuimus quod mulier inhonesta vel alias suspecta que scitur, ad domum altaristarum ultro non ducatur, si autem casu in suo vel forte alterius missa negocio domum sua sponte intraverit, in

121 Thess 5,22. 
anteriori parte domus breviter in suo facto expedita discedat. Si qua autem honesta venerit, habens secum sociam vel aliam personam honestam sibi iunctam, potest altarista in comodo suo conferre secum honeste id, quod fuerit oportunum aperto tamen comodo, ita quod suspicio evellatur. Si vero sola venerit, non habens secum sociam, in anteriori parte domus aut ante coquinam, vel alias in ambitu sive in stuba communi, si hieme fuerit, in suo facto disponatur. Si autem aliquid reponere sive recipere secretius in comodo altariste habuerit, si probata fuerit persona, de qua nil sinistri unquam est auditum, et presertim si provecte fuerit iam etatis, facta relacione seniori vel ipsi preposito absente seniore si approbaverit, potest solus cum sola votum illius adimplere; si vero non approbaverit, adhibeat sibi socium alium altaristam sive aliam quamcunque personam, potest tamen altaristam habens testem secum in camera sua tecas de plumis vel pulvillis per mulierem abstrahere et easdem superducere viceversa. Si autem preter formam premissam aliquis mulierem ad cameram suam sine teste introducere presumpserit, de quo si convictus fuerit, primo dabit unam sexagenam grossorum; quod si secundo hoc fecerit, debet de consorcio altaristarum sine spe redeundi ad eosdem profugari; secus autem fiat, si casu altarista eam non vocante cameram ipsius intraret, dummodo surgens eam honeste quantocius evaserit. Similiter volumus hoc intelligi de ludo alearum aut taxillorum, sive eciam pulsu vel [s. 106] volucione globorum, quos ludos cum ceteris nullus audeat ludere in domo eadem.

\section{$\left[\begin{array}{ll}\S & 10\end{array}\right]$ De custodia et clausura domus.}

Dignum est, ut domus deodicata nullis fiat in proverbium, sed ceteris amplioribus excubiis custodiatur aliis in exemplum, statuimus quod domus altaristarum debita hora claudatur: in estate hora secunda, in hieme vero hora tercia noctis. Si vero aliquis post horas antedictas domum intraverit aut ostium pulsaverit sive nola, solvat pro pena III grossos. Item si quis personam extraneam in comodo suo aut in domo sine licencia senioris vel prepositi pernoctaverit, solvat pro pena II grossos.

\section{$[\S 11]$ De pernoctacione extra domum.}

Sine suspicione sinistra vix esse poterit, ut altariste dimissa honesta requie habitacionis proprie dormiant in hospicio alieno. Providimus quod nullus altaristarum extra domum pernoctet. Quod si facere presumpserit et in loco honesto repertus fuerit et ex causa racionabili, solvat pro pena I grossum. Si autem in loco inhonesto et de hoc legitime convictus fuerit, solvat comunitati I sexagenam. Si autem notam infamie incurrerit et se non expurgaverit tanquam infamis remanens, ut putridum membrum a consorcio altaristarum irrevocabiliter rescindatur. Si autem aliquem necessitas urgebit, racionabilis et notabilis facti declaracione facta seniori, facere potest iuxta eiusdem decretum.

\section{$[\S 12]$ De preeminencia prepositi.}

Quia onera comunia minus ledunt, dum alternatim in comunitate sufferuntur, statuimus quod quilibet in domo altaristarum manens prepositet unum mensem iuxta ordinem introitus sui et secundum consuetudinem in dicta domo diu tentam sub pena unius sexagene. Ipse idem prepositus, qui pro tempore fuerit, pecuniam singulis ebdomadis pro bursa per fratres positam sublevabit et pro eadem fratribus et familie cibaria ministrabit, addiciones, si necesse fuerint, de propriis suppletive ministrando, quas semper feriis secundis a fratribus recipiet viceversa. Ipse eciam de serotino 
fratrum adventu et pernoctacione extra domum curam gerat delinquentesque in hac parte puniendos deferat comunitati. Volumus insuper, quod quilibet prepositus pro prandio et cena certam horam fratribus deputet comedendi, tam diebus festivis quam diebus ieiunii [s. 107] ac eciam feriatis, ipsam horam scripture tabule comuni annotando vel alias comunitati verbo insinuando. Et quia monstruosum et admiracione dignum videtur, ut corpus in membris bene dispositum capite careat, statuimus ut prepositus pro tempore existens durante prepositura sua domum et bonum comunitatis dirigat. Ipse primatum in mensa tenebit et ut unusquisque fratrum ibidem in silencio comedet, panem suum quantum valet procurabit, garrulos et varia loquentes silencio suffocando. Ipse fratres ad tractandum causas et negocia domus convocabit, verbum comunitatis coram quocunque concionando perorabit vel perorari commitat, in convencione fratrum quemlibet eorum singillatim et de per se secundum voces eorum, quid cuilibet iustius ac melius videbitur, per ordinem queritabit. Ipse vocibus auditis singulorum, quod mere erit iusticie attendens, quod Domini est iudicium non personam accipiens, sed solum Deum pre oculis, habens cum bona deliberacione secundum pluralitatem vocum concludens diffinitivam pronunciabit sentenciam, a qua ulterius nulli licebit appellare sub pena exclusionis de domo. Penasque ab excedentibus seu quovismodo delinquentibus nulli parcendo irremissibiliter a quolibet extorquere, idem prepositus sit astrictus.

[\$ 13] De noviciis volentibus habitare in domo altaristarum et eorum sponsione.

Quia nulla est mandantis auctoritas, nisi esset qui mandatum timens ex timore vel amore exequetur, statuimus ut singuli societate altaristarum gaudere volentes ac cum eis in domo habitare, veniat ad eorum comunitatem cum notario publico et testibus asserens eis III marcas pecunie pro introitalibus cum tali forma verborum: Coram vobis notario et testibus presentibus ego $\mathrm{N}$. sponte et de bona voluntate antiquam consuetudinem et statuta altaristarum in hac domo manencium approbando, affero eisdem III marcis pro introitalibus et promito sub bona fide eas non repetere nec aliquo iure pro eis agere, si unquam domum exire contigerit sponte vel per repulsam senioris ac fratrum, et promito obedienciam domino seniori et successoribus suis, in omnibus licitis et honestis domum concernentibus statuta et statuenda pro bono domus facta et fienda polliceor observare sub penis in statutis et privilegio eorum expressis. $<$ Sic me Deus adiuvet et hoc sanctum Ewangelium. $>$ Et reponet 3 marcas comunitati.

[s. 108] [ $\$ 14]$ De reverencia altaristarum et prepositum habendum ac de observanciis mense et coquina.

Quia decens est, ut maioribus honor deferatur et alter alterum inter fratres non provocet ad iram, statuimus quod nequaquam aliquis altaristarum audeat prepositum aut alter alterum inter fratres verbis pungitivis publice turbare, aut mense cibaria vituperare vel eadem aliquomodo taxare, sive etiam ante plenam eorum decoctionem prepositum vel ipsam cocam verbis stimulativis afflictis addendo afflictionem strangulando quomodolibet molestare, vel eciam importune eosdem solicitando in damnum comune iocose vel moleste inclamare, ne cibos incoctos talismodi perculsi sugillacionis molestia mense cogantur ante tempus superferre vel dicta cibaria contra voluntatem prepositi et eius disposicionem sale vel radicibus alias quam coce commiserit condire, aut eciam eadem alio quocunquemodo disponendo ordinare, vel porcionem suam cicius forte eligendo meliorem tempus preveniendo comune de 
olla seorsum recipere vel panem eciam de iure communi taliter pinguedinem minuendo preventive perfundere. Causa tamen accedente racionali de licencia prepositi talia fieri bene possunt mensam eciam ante tempus et notanter diebus ieiunii tegere vel ad eandem alias quam oportet pulsando signare preter voluntatem prepositi et preceptum. Porcionem suam vel alias de mensa sine licencia senioris vel prepositi sive eciam communitatis in absencia eorum videlicet cuilibet porrigere vel servare, quod si quis facere presumpserit et a preposito monitus non cessaverit, penam IIII grossorum incurrit. Si quem autem altaristarum certos defectus et infirmitates in se habentem cibos aliquos propter condimenta ipsorum comunia oportet evitare et evitando carere, potest prepositus coce commitere porcionem suam ante condimentum ipsius de olla excipere et eandem condimento ipsius defectuosi proprio et speciali pro libitu suo seorsum condiendo preparare. Omnis eciam altarista, qui hora cene comunis propter indigestionem cibi sumpti in prandio simul cum aliis in comunitate non audebit manducare, potest de licencia prepositi tale quid licet in parte, quod est partibile ad tempus sibi aptum ad edendum reservare vel coce alias reservandi commitere. Ne taliter cena frustratum communi oporteat alias in civitate sibi cenam ad fautores de novo fiendam tempus negligendo evagare, si vero prepositus minus bene providerit, ex communi consensu dominorum unus de fratribus, cui commissum fuerit, piie informet eum, ut diligencia maiore apposita dominis lautius provideat in expensis et necessariis comparandis.

[s. 109] Si autem aliquem de fratribus contingat aliquot dierum sit in vigilia Betae Virginis vel alicuius apostoli ex devocione serofayzare, talis significabit preposito suam voluntatem et prepositus afferet sibi duos quadrannos iuxta morem diu tentum et observatum in subsidium.

Si quis de fratribus fuerit vocatus ad aliquod convivium extra domum tociens quociens, talis invitatus pro qualibet vice debet insinuare preposito vel coctrici tempore ante condecenti, ut prepositus sciet bursam moderare secus non facturus.

$[\S 15]$ De eo, quomodo se domini habere debeant in convocationibus et consiliis, sive etiam in responsionibus eorundem.

Ut eciam inter dominos sit continua caritas et disciplina, statuimus ut in consilio quilibet in voce sua sit circumspectus, solum pro bono comuni loquatur nullius personam confundendo. Quod si aliquis capitosus et sui honoris immemor aliquem ex dominis, iuvenem aut senem, parvipendere et vilipendere aut vocem alterius contumaciter confundere presumpserit, ex tunc statim prepositus domus in eadem convocacione puniat eundem incompositum in II grossis, quam penam idem excedens statim deponat aut pignus invadiet, et sibi silencium prepositus idem imponat. Et si a verbis superfluis et inutilibus cessare noluerit aut penam statim aut vadium dare recusaverit, penam dupli incurrat; et si secundo monitus non cessaverit et contumaciter mandatis et hortacionibus prepositi se opposuerit, ab eadem convocacione excludatur et penam graviorem contra talem rebellem et pacis inimicum ceteri domini altariste dictent; quam penam si non dederit infra octo dies, a domo altaristarum penitus excludatur. Et eadem pena sit illis, qui ad quesita prepositi in convocacione ex protervia vel animositate ipsorum respondere contemptive et frivole moram faciendo, noluerint, tempus perdendo silencio et dominos in aliis negligendo et eosdem per hoc ipsum non modice perturbando; vel si responderint vel tunc rancore et furore, vel 
tunc super aliquos e fratribus in facto ipsorum suspicionem proycientes inceperint iurgari contra eos, quasi ipsi fuerint in facto eorum actores pariter et auctores, illa pretermitentes, ad que debuerint respondere; quos tamen prepositus [s. 110] primo, secundo et tercio in spiritu levitatis admonendo motus primos ad eisdem taliter repellendo paterne tunc tenetur sustollare, ne penas prescriptas taliter rapti nescientes quomodo easdem subintrarent et post modum acerrime perdolenter non tantum de penis, quantum de divisione et fraterna wlnerata caritate, quod utique caritas inter fratres apareat, que onus alterius utique portare, tenetur nec non eciam de damno eiusdem, veluti de suo dolere consuevit; imo eciam verisimiliter obligatur. Si autem audire noluerit, secundum prescripta puniatur.

Placuit etiam, ut quibus idem prepositus sive comunitas ad respondendum sive eciam coram ipso vel ipsa comunitate aliud quid faciendum terminum certum prefixerit et ipsi dicto termino contumaciter parere non curaverit, vel si paruerit, tamen commissa prepositi et comunitatis complere non curaverit, primo pro pena dabunt VI gr, secundo XII, tercio vero comunitas contra tales dictet penam graviorem, quam si infra octo dies non soluerint, a domo altaristarum penitus excludantur. Debent eciam huiusmodi ante diem et notanter ipso die responsionis vel cuiuscunque alterius actionis sive facti super eisdem fiendis ipsum dominum prepositum vel comunitatem solicitando ammovere, et non prepositus sive comunitas, respondendum sive eciam aliud quid agendum.

Volumus eciam ut cum prepositus domus ceteris in domo dominis conveniendi terminum certum et horis pariter ad aliquid tractandum prefixerit, quod quicunque tunc se subtrahendo non interfuerit vel alias nimiam fecerit moram alios negligendo et causam absencie sue racionabilem ante convencionem preposito domus non declaraverit, penam IIII grossorum incurrat.

Debent eciam fratres et domini se invicem ad hoc ipsum adhortari alter alteri memorie reducendo, ne forte studiis vel oracionibus vel aliis quibuscunque negociis occupati talia de mente excuciant et penales existent. Quod utique caritas inter fratres habeatur, prepositus tamen huiusmodi terminum conveniendi et horam pariter non sub divinis prefigere oficiis debet, similiter ne sermonis, sed alias quandocunque, nisi tunc ardua evenerit necessitas. Non potest tamen nec debet excusari a pena, qui per oblivionem huiusmodi convocacioni non interfuerit, licet eciam per fratres ceteros, ut premititur, ad eandem non fuerit iterato avisatus. Sufficit enim huiusmodi quod scivit, oportet enim unumquemque fratrem providum in talibus et oculatum semper fore.

[ $\$ 16]$ De voce danda in consilio.

[s. 111] Statuimus ut, singuli domini altariste in consiliis domus suas voces plenas habentes, nullus in vocem alterius prorumpat, sed uno loquente ceteri taceant; quo loqui cessante, si quispiam racionem meliorem habuerit, poterit cum reverencia eiusdem domini et seniore domus consenciente racionem suam in medium proponere pro bono comunitatis incremento. Quod si quis dominorum prevolans fuerit et vocem alterius interrumpit, II grossos irremissibiliter pro pena exolvat. Vocum autem inquisicio incipi debet ab ultimis et gradu ascensu cendi consequens successive usque ad primos.

[ $\$ 17]$ Sequitur de familia quomodo domus fovenda, simul et de iure illorum, qui pro tempore absentes fuerint pariter et presentes. 
Quod omnes tangit ab omnibus ${ }^{13}$, supportetur, statuimus, quod si aliquem illorum ex legitimis causis cum licencia prepositi quare ad aliquot ebdomadas exire contingerit, de qualibet ebdomada communitati II quadragenas, et hoc intelligendum est de illis, qui sunt continui in domo et in mensa. Si vero eciam ex licencia domus in Cracovia existens altarista vel alias ubicunque, qui tamen tempore suscepcionis ipsius in domum, ut premititur, III marcas pro introitalibus comunitati depagavit, se a mensa absentaverit et cum fratribus in domo simul et in mensa non, ut tenetur, continue commanere voluerit, de anno quolibet comunitati III marcas ut ceteri altariste comunem familiam domus melius possint conservare, simul et onera domus, que multa et varia in ibi existunt, per hoc ipsum utcunque valeant moderare. Qui insuper ad singulas contribuciones composicionum pro domo reformanda fiendas, que absencie ipsius tempore occurerunt, cum singulis altaristis prescriptis aliisque in domo degentibus, et notanter pro tristega educenda, equaliter contribuere sit astrictus. Secus autem fiet, de his qui peregre proficiscentur, vel simpliciter in negocio domus mitentur, vel eciam, quod absit, forte citati calumpniose sive ad perhibendum testimonium veritati absentari ad tempus, licet inviti, compellentur; si vero citari merebuntur, alias vel ipsi citabunt ad singula tunc prescripta persolvenda similiter sunt astricti, alias enim ad nichilum fuissent obligati, sicut peregrini prescripti et qui eosdem commitantur.

\section{$\left[\begin{array}{ll}\S & 18\end{array}\right]$ De lectura ad mensam.}

Ad evitandum inutiles garrulaciones placuit, ut sicut corpus materialibus alitur cibis, ita et mens intus pingwedine spiritualium recreetur, quilibet dominorum secundum ordinem qui tenetur in mensa legat per unam ebdomadam ad mensam communem pro se vel [s. 112] per alium, qui si legere neglexerit, pro qualibet lectione obmissa dabit unum quadragenam pro pena ubi, nulla causa excusacionis admitatur, preter ipsos decumbentes pariter et absentes.

\section{[ $\$ 19]$ De locis dominorum habendis circa mensam.}

Omne seminarium invidie, displicencie et rancoris extirpandum esse perhibetur, ut caritas posset firmius radicari. Volumus unanimiter, quod domini altariste sibi mutuo honorem deferent, nichilominus quilibet, quod sibi debetur, de iure non ammitat, posterior ad domum intrans cedat priori in mensa et locum eminenciorem non usurpet, nisi prior libere condescenderet et posteriorem in loci eminencia preferret, sub pena unius grossi.

\section{[§ 20] De tempore quo debent legi statuta domus.}

Ne quis ignoranciam pretendens penam horum statutorum incurrens se possit excusacione, tueri placuit, quod quilibet prepositus pro tempore existens singula statuta per se vel per alium distincte legat bis in anno, videlicet circa festum Vrbani et Andree, sub pena quatuor grossorum.

$[\S 21]$ De hoc quomodo aliquem dominum deceat ambulare nocturno tempore.

Cum non deceat quempiam tempore nocturno per plateas vagari civitatis, statuimus ut nullus dominorum, ut nocti corax lumen odiens, post horam noctis terciam extra

${ }^{13}$ Sexti Decretalium V, XII, XXIX; por. Corpus iuris canonici, t. II: Decretalium collectiones, wyd. A. Friedberg, Graz 1959, kol. 1122: Quod omnes tangit debet ab omnibus approbari; W. Uruszczak, Reguła quod omnes tangit debet ab omnibus approbari dawnego prawa kanonicznego i jej znaczenie, w: Servabo legem in toto corde meo. Księga pamiątkowa dedykowana księdzu profesorowi Józefowi Krzywdzie CM, dyrektorowi Instytutu Prawa Kanonicznego UPJP II z okazji 70. rocznicy urodzin, Kraków 2013, s. 545-559. 
ambulet in plateis sine candela et societate honesta, nec eciam nocturno tempore sive diurno in comodo suo aut alibi in domo insolencias faciat, quibus alii domini quiescentes aut studiis suis inherentes possent impediri, sub pena IIII grossorum.

$[\S 22]$ De discordantibus.

Duobus inter se discordantibus partibus adherentium viscera contremiscunt, statuimus quod si quis dominorum contra fratrem suum causam rixosam vel offensivam in domo exortam habuerit, sine strepitu soli preposito domus causam suam proponat et prepositus causam eandem comunitati dominorum insinuet et sentenciam diffinitivam ab illis proferat, a qua nulli licebit appellare sub pena unius sexagene, ne facta domus caritative tractata in publicum evolent in scandalum et proverbiorum plurimorum. Si vero aliqua pars dominos suspectos habuerit, causam suspicionis contra eos proponat, quam causam ceteri diiudicent; si racionalis fuerit admitatur et causa eadem sine suspectis terminetur, si vero causa legitima non fuerit; non poterit eos a consilio repellere. Si vero una pars totam comunitatem domus suspectam habuerit et velit forum communitatis declinare, signum est quod querit effugium cum non sit verisimile quod facta comunitas plus erraret quam solus, qui solus sue sentencie innititur, ideo si iuri altaristarum parere noluerit, dabit communitati decem marcas. [s. 113] Insuper, qui sub eadem promissione nullus secreta domus in convocacionibus proposita seu tractata per modum secretorum personis extraneis revelet, quod si aliquis de revelacione talium convictus fuerit, a talibus convocacionibus debet excludi et, si videbitur comunitati, puniri poterit pena maiori per communitatem arbitranda.

\section{[ $\$ 23]$ De pace conservanda et antiquis litibus non suscitandis.}

Quia optimum bonorum est pax in communitatibus et concordia, ideo pro bono pacis intimius conservando et radices iurgiorum radicitus extirpando, statuimus quod nullus dominorum lites mortuas et sopitas aliquomodo movere aut suscitare presumat. Quod si quis fecerit, signum est, quod radix invidie et ody in eodem amaricata prona sit malum proximo germinare, ideo in duobus grossis puniatur.

\section{[ $\$ 24]$ De libraria custodienda.}

Quia nisi adhibeatur solicitudo custodie, libri, qui a pluribus in usus recipiuntur, facillime distraherentur et per consequens deperderentur, statuimus quod quolibet anno duo eligantur custodes, qui solicitudinem habebunt custodire libros et plenum posse accomodare personis fidedignis.

Quibus specialibus punctis statutorum pro meliori et saniori in medium deductis, revertamur ad reminiscenciam patrum priorum huius domus et hereditatis erectorum, ut pro tanto fervencius eorum memoria agatur oracionibus cum devotis a fratribus huic domui notis.

\section{BIBLIOGRAFIA}

Baster M., Bursa Stranigielska. Z dziejów kolegiów Uniwersytetu Krakowskiego w XVII i XVIII wieku, Kraków 2015 (Historia et monumenta Universitatis Jagellonicae IV).

Czarciński I., Bractwa w wielkich miastach państwa krzyżackiego w średniowieczu, Toruń 1993.

Elbel P., Krupa N., Die Fraternitas XXIV plebanorum civitatum regalium in Oberungarn und der Handschriftenbestand Zipser Pfarreibibliotheken, w: Pfarreien im Mittelalter. Deutschland, Polen, Tschechien und Ungarn im Vergleich, Göttingen 2008 (Studien zur Germania Sacra 32). 
Forgó A., Bruderschaften in Ungarn. Eine Forschungsbilanz w: Bruderschaften als multifunktionale Dienstleister der Frühen Neuzeit in Zentraleuropa, Wien 2018 (Veröffentlichungen des Instituts für Österreichische Geschichtsforschung 70).

Gill M.L., Unity of Definition in Metaphysics H.6 and Z.12, w: Being, Nature and Life in Aristotle, Cambridge 2010.

Gottschalk J., Das Totenbuch der Altaristenbruderschaft von Maria Magdalena zur Breslau ca. 1454-1524, Archiv für schlesische Kirchengeschichte 6, 1941.

Hengst K., "Fraternitas sacerdotum in Herfordia". Die Dreifaltigkeitsaland in Herford, w: Lob der brüderlichen Eintracht. Die Kalandsbruderschaften in Westfalen. Festschrift aus Anlaß des 650-jährigen Bestehens der Kalandsbruderschaft in Neuenheerse, Paderborn 2000 (Veröffentlichungen zur Geschichte der mitteldeutschen Kirchenprovinz 17).

Heyden H., Kirchengeschichte Pommerns, t. I, Köln 1957.

Jeuniaux P., Les communautés de "prêtres-filleuls". Longévité d'une institution née au XIVe siècle, Mémoires de la Société des Sciences Naturelles et Archéologiques de la Creuse 42, 1984-1986.

Kozłowska-Budkowa Z., Odnowienie jagiellońskie Uniwersytetu Krakowskiego (1390-1414), przedruk w: tejże, Studia z dziejów kultury sredniowiecznego Krakowa, wybór S. Szczur, Kraków 2015 (Biblioteka Krakowska 146).

Kuiken K., Rural Salvation Markets. Medieval Memoria in Dutch Village Parisches, Groningen 2019 (Historia Agriculturae 49).

Kumor B., Kościelne stowarzyszenia świeckich w okresie przedrozbiorowym, Prawo Kanoniczne 10, 1967.

Kuraś S., Statuty i przywileje bractwa kapłanów dekanatu zatorskiego 1378-1525, Polonia Sacra 7, 1955.

Leotoing d'Anjony de G., La communauté des prêtres-filleuls de l'église Notre-Dame d'Aurillac, Revue de la Haute-Auvergne 33, 1952-1953, 34, 1954-1955.

Meersseman G.G., Die Klerikervereine von Karl dem Großen bis Innocenz III, Zeitschrift für schweizerische Kirchengeschichte 461952.

Nowacki J., Dzieje archidiecezji poznańskiej, t. II, Poznań 1964.

Oberste J., Gibt es eine urbane Religiosität des Mittelalters?, w: Städtische Kulte im Mittelalter, Regensburg 2010 (Forum Mittelalter. Studien 6).

Orlita Z., Fromme Bruderschaften in Böhmen, Mähren und Schlesien. Ein Forschungsüberblick, w: Bruderschaften als multifunktionale Dienstleister der Frühen Neuzeit in Zentraleuropa, Wien 2018 (Veröffentlichungen des Instituts für Österreichische Geschichtsforschung 70).

Raczkowski W., Konfraternie duchownych w wielkopolskiej części diecezji poznańskiej w okresie przedtrydenckim (XV-XVI w.), Lublin 1966 (maszynopis).

Skierska I., Obowiązek mszalny w średniowiecznej Polsce, Warszawa 2003.

Szymborski W., Odpusty w Polsce średniowiecznej, Kraków 2011.

Tarbochez G., Les communautés de prêtres séculiers en France à la fin du Moyen Âge, Revue d'histoire de l'église de France 93, 2007.

Uruszczak W., Reguła quod omnes tangit debet ab omnibus approbari dawnego prawa kanonicznego i jej znaczenie, w: Servabo legem in toto corde meo. Księga pamiątkowa dedykowana księdzu profesorowi Józefowi Krzywdzie CM, dyrektorowi Instytutu Prawa kanonicznego UPJP II z okazji 70. rocznicy urodzin, Kraków 2013.

Wiśniowski E., Bractwa religijne na ziemiach polskich w średniowieczu, Roczniki Humanistyczne 17, 1969.

Wiśniowski E., Parafie w średniowiecznej Polsce. Struktura i funkcje społeczne, Lublin 2004.

Wójcik-Zega D., Codex legum venerabilis communitatis Collegii Maioris. Studium kodykologiczno-źródłoznawcze księgi statutów Kollegium Większego Uniwersytetu Krakowskiego (Archiwum Uniwersytetu Jagiellońskiego, rękopis 68), w: Felix indiget amicis. Studia z dziejów kultury duchowej i intelektualnej średniowiecza ofiarowane Profesorowi Krzysztofowi Ożogowi, Kraków 2016. 
Wyrozumska B., Starzyński M., Materiały do historii altarystów kościoła Mariackiego w Krakowie w średniowieczu, cz. 1: Kalendarz i nekrolog oraz katalog altarystów i benefaktorów, Roczniki Historyczne 84, 2018.

Zaremska H., Bractwa w średniowiecznym Krakowie. Studium form społecznych życia religijnego, Wrocław 1977.

\title{
Materials for the history of altarists of Virgin Mary Church in Cracow in the Middle Ages
}

Part 2: Statutes of the house of altarists

\begin{abstract}
Summary
The second part of source materials for the history of the house of altarists of Virgin Mary Church in Cracow in the Middle Ages presents a critical edition of the statutes of the house, the only source of this type known from the area of the historical Kingdom of Poland. The genesis of the altarist fraternity serving at the main parochial church in Cracow most probably dates back to the last quarter of the $14^{\text {th }}$ century. It was, therefore, one of two oldest known priestly fraternities in Little Poland. From 1397 the Virgin Mary altarists lived together in a house in the Little Market, remaining under the patronage of the city council of Cracow. The terms of living in the community were regulated by the statues published here, containing 24 articles. They were drafted in 1407 at the latest. The surviving redaction is later by thirty years (1437). The contents is similar to the known statutes of university colleges and halls. Early modern notes with comments written on the margins of the manuscript show that the statutes were still in use in the $16^{\text {th }}$ and $17^{\text {th }}$ centuries.
\end{abstract}

